\title{
Management of Unexpected Expenditures for Covid-19 in Local Government
}

\author{
Yesi Mutia Basri ${ }^{1 *}$, Hariadi ${ }^{2}$, Ode Asra ${ }^{3}$
}

AFFILIATION:

1,2,3 Faculty of Economics and Business, Universitas Riau, Indonesia

\section{*CORRESPONDENCE:}

yesimutia@gmail.com

THIS ARTICLE IS AVAILABLE IN:

https://ojs.unud.ac.id/index.php/jiab

DOI:

10.24843/JIAB.2021.v16.i02.p06

\section{CITATION:}

Basri, Y. M., Hariadi, H., \& Asra, O. (2021). Management of

Unexpected Expenditures for Covid19 in Local Government. Jurnal IImiah Akuntansi dan Bisnis, 16(2), 264-278.

\section{ARTICLE HISTORY}

Received:

20 March 2021

Revised:

14 July 2021

\section{Accepted:}

22 July 2021

\begin{abstract}
This study aims to explore how the Riau Provincial Government manages unexpected expenses in the face of the Covid-19 pandemic. The method in this study is a qualitative method with the type of case study. Data collection techniques used are interviews, observation, and documentation. The results showed that the management of unexpected costs was carried out through the planning stage by reallocating and centralizing the budget. At the administrative and accountability stage, there are problems in recording Unexpected Expenditures, namely the absence of clear technical guidelines regarding the implementation of Unexpected Expenditures, setting spending limits for emergencies. There is no valid data for the distribution of aid funds for MSMEs affected by Covid-19 as well as valid documents for recording third party grant assistance. This research contributes to the government in making policies in financial management in disaster emergencies.
\end{abstract}

Keywords: Covid-19 pandemic, financial management, refocusing, reallocation, administration

\section{Introduction}

The World Health Organization (WHO) explains that Corona viruses (Covid) is a virus that infects the respiratory system. This infectious virus is called Covid-19. The spread of the Corona virus is very fast even across countries. To date, 188 countries have been confirmed by the Corona virus. The spread of the Corona virus to various parts of the world has an impact on the Indonesian economy, both in terms of trade, and investment \& tourism. President Joko Widodo has officially declared the disease caused by the corona virus or Covid-19 as a national disaster. The determination of Covid-19 as a national disaster is stipulated in Presidential Decree (Presidential Decree No. 12 of 2020) concerning the Determination of Non-Natural Disaster for the Spread of Corona Virus Disease 2019 (Covid-19) as a national disaster.

With the stipulation of Covid 19 as a national disaster, the government must provide large funds to respond Covid disaster. The efforts made by the government were to make changes to the budget and shift the budget to be more prioritized for the prevention of Covid 19. In this regard, the government has issued Laws and Regulations 
(Perpu) Number 1 of 2020 concerning State Financial Policy and Financial System Stability for handling the Covid-19 Pandemic. The regulations broadly discuss two things; the first is state financial policy and regional finance, namely set income, expenditure, and financing policies. The second is the financial system stability policy, which includes policies to deal with problems with financial institutions that endanger the national economy and/or the stability of the State financial system. This policy is also regulated in Law number 17 of 2003. Regarding State Finances, Article 28 paragraph (4) states that in a state of emergency, regional governments can make expenditures for which no budget is available.

As a form of immediate next step, the government issued (Presidential Instruction No. 4 of 2020) about "refocusing activities, budget reallocation, and procurement of goods and services to accelerate the handling of the 2019 corona virus disease (Covid-19) ". Following up on Presidential Instruction No. 4 of 2020, the Minister of Home Affairs issued Permendagri Regarding the Acceleration of Handling Covid-19 in Local Government Environments. Minister of Home Affairs asked the regional government to immediately make changes to the budget allocation for handling the Covid-19 pandemic. This directive has been confirmed in the Minister of Home Affairs Instruction issued on April 2, 2020.

Based on Permendagri No. 20 of 2020, the Riau Provincial Government has shifted the budget by 234.8 billion. In addition, there was the mobilization of Special Allocation Fund (DAK) and Regional Incentive Fund (DID), both regencies/cities, and Riau Province, amounting to IDR 1.17 trillion, which was diverted for handling Covid-19. This budget shift refers to the mandate of budget changes and is prioritized on 3 aspects, namely health, economy, and social safety nets. The budget reallocation in the Riau Local government budget (APBD) has been carried out twice. In the first stage, the funds reallocated to accelerate the handling of the corona virus in Riau amounted to IDR 74.9 billion. The budget is more focused on the health aspect, the health office has received IDR 46 billion in the disbursement of funds, and several hospitals have received funds in between, namely the Arifin Ahmad Regional Hospital of IDR 3.5 billion. Petala Bumi Regional Hospital of 1.2 billion, and the Handsome Mental Hospital of IDR 2.3 billion. Meanwhile, in the second stage, which is IDR 400 billion. The government takes priority policies, namely, social safety nets and social assistance, safety and health, and handling of economic impacts. In the second stage, the Riau Provincial Government focused more on the budget for handling the Covid-19 Pandemic on social safety nets, this can be seen from the amount of budget allocated for social safety net posts which amounted to more than IDR 211 billion. There are six social safety net programs as an effort to reduce the impact of Covid-19, including PKH policies, food cards, pre-employment cards, electricity rates, anticipating basic needs, and providing credit payment relief for informal workers, both online motorcycle taxis, taxation drivers, and MSME players.

Of the total reallocation and refocusing budget, 372.59 billion was allocated to Unexpected Expenditures (BTT), while 26.80 billion was allocated to Financial Assistance Expenditures. This BTT allocation is used for handling health impacts, social safety nets, and handling economic impacts. (source: data from Office for Management of Regional Revenue, Finance and Assets (BPKAD) Riau Province). The occurrence of budget changes and budget shifts has created new problems in the management of government finances, especially in the management of Unexpected Expenditures (BTT). Unexpected expenditure is an expenditure that is used to back up budgets that are not budgeted for 
direct expenditure. Unexpected expenditures are expenditures that do not have details and are only a single account and have resulted in several problems starting from the planning stage, administration to the accountability process.

In practice, managing unpredictable spending creates problems. The results of the researchers' interviews with informants showed that the administration of unexpected expenditures caused polemics, for example, who should be the manager and what use of unexpected expenditures is allowed. The use of unexpected expenditures itself has been given the convenience so that it can be immediately disbursed within 1 day after submitting the Expenditure Activity Plan (RKB). Therefore, this study explores further how the management of unexpected expenditures in the Riau Provincial Government in dealing with Covid-19 and what problems occur behind the management of these unexpected expenditures.

Based on the phenomena that occur above, the researchers are interested in researching the management of Unexpected Expenditures and what are the obstacles faced by the Riau Provincial government in managing the Unexpected Expenditures. This research is qualitative research with case studies. According to (Creswell. J.W, 2015), A case study is a research that explores a bound system or a case (or it could be several cases) that occurred over a certain period through in-depth and detailed data collection from various sources of information that can be trusted to testify. Information gathering in case of studies according to Creswell can be done by conducting interviews with informants, direct field observations, as well as various documents and reports that already exist and audiovisual materials.

Previous similar research on the financial accountability of natural disasters, namely natural disasters that have often occurred as in research (Rivani, 2017), namely about the mechanism of financial accountability from natural disasters such as tsunamis and earthquakes and in research (Hasanah, 2019) on financial accountability for disaster management. In contrast to previous studies, because of the natural disasters that occurred in Indonesia, namely the Covid-19 pandemic, this is the first time that has occurred in Indonesia, even the first time this has occurred in the world and this research specifically examines how the management of unexpected spending in handling Covid-19 in the Riau provincial government. This research has contributed to the Riau Provincial Government in determining financial management policies related to emergency disaster management not only facing the Covid-19 Pandemic.

Satriajaya (2018) examines financial management with the management of specific financial assistance in the village budget and expenditure income. His research examines dysfunctional behavior in financial management, especially in villages in Samanta Regency. Then another research also examines how financial management practices are carried out by (Triani \& Handayani, 2018); (Meutia \& Liliana, 2017); (Arifiyanto \& Kurrohman, 2014). This research is devoted to the village government. Other research related to financial management in government uses more quantitative research methods. For example; Budiarso et al (2015), Triani \& Handayani (2018), Nafidah \& Anisa (2017).

In this study, the researcher presented several theoretical studies and concepts that were relevant to the context of this research phenomenon, but the theory and concept studies presented were not explicitly related to the phenomenon. This is based on the opinion of Schwandt (1993) in Creswell (2015) who states that qualitative research is not purely for observing theory, so that theory is "passive" and only becomes 


\section{Basri, Hariadi \& Asra \\ Management of Unexpected Expenditures for Covid-19 in Local Government}

the starting point for the whole observation. The theory is only a "help" for researchers in determining perspectives according to the formulation of the problem posed (Creswell, 2015). Following inductive logic (Punch, 2005 in Creswell 2015) theory will still be endpoint research because research starts from data collection, then to general themes, which then leads to a pattern, model, and ends at a particular theory. The final results of this study are expected to add to the literature on the application and justification of some of the above theories in public sector accounting, especially regarding local government financial management.

\section{Research Method}

This study uses a qualitative research method based on the post-positivism philosophy used to assess the condition of natural objects, where the researcher is the key instrument, the sampling of data sources is done purposively and snowball, the technique of collecting is triangulation (combined), the data analysis is inductive/qualitative. and research results emphasize meaning rather than generalization (Sugiyono 2009). This research is a case study research conducted at the Riau Provincial Government. Qualitative research was chosen to study how Covid-19 financial management in depth, not only looking at regulations and reports. The case study was used to explore how to manage unexpected expenses in handling Covid-19 in the Riau Provincial Government. The selection of research locations was based on the initial survey that there were problems in managing unexpected expenditures in handling Covid-19. Case studies were conducted by in-depth interviews. The selection of case studies is also recommended if the investigator cannot control for the presence of events.

The informants in this study consisted of key informants, main informants, and supporting informants. The selection of informants is based on their knowledge of the object or situation we want to study. Key informants are informants who have comprehensive information about the problems raised by the researcher, in this case, are Head of the BPKAD Budget Division, Head of Regional Treasury, and Treasury and Head of Accounting and Reporting BPKAD.

Key Informants are people who know technically and in detail about the research problem to be studied. In this study, the main informants were Subdivision of planning and health department programs, Subdivision of Program Development and Budgeting of Arifin Ahmad Hospital, Head of the MSME Empowerment Section of the Cooperatives, and MSMEs Service. While the supporting informants are people who can provide additional information as a complement to the analysis and discussion in qualitative research. The supporting informant in this research is the Section Head of Jadirejo Urban Village people's welfare. Informants in the research carried out are as Table 1.

In this section of the discussion, the researcher will describe in detail how the financial accountability of the Riau Provincial Government due to the Covid-19 pandemic. The research method that has been implemented is the data collection system through observation, interviews, and documentation

Data collection in research is carried out in several ways. According to Sugiyono (2012; 402), there are various data collection techniques, namely: interviews. The interview technique used is through in-depth interviews. 
Basri, Hariadi \& Asra

Management of Unexpected Expenditures for Covid-19 in Local Government

Table 1. List of Research Informants

\begin{tabular}{|c|c|c|c|}
\hline No & Name & $\begin{array}{l}\text { Informant } \\
\text { characteristics }\end{array}$ & Position \\
\hline 1 & $\begin{array}{l}\text { H. Ispan S. Syahputra HS, } \\
\text { MM }\end{array}$ & Key informants & Head of Budget Division \\
\hline 2 & Afdillah Arifin, SE, MM & Key informants & $\begin{array}{l}\text { Head of Cash and Treasury } \\
\text { Division }\end{array}$ \\
\hline 3 & Hartono, Ak, M.Si & Key informants & $\begin{array}{l}\text { Head of Accounting and } \\
\text { Reporting Division }\end{array}$ \\
\hline 4 & Achmad Jajuli, SKM, MKM & Main informant & $\begin{array}{l}\text { Subdivision of planning and } \\
\text { health department programs }\end{array}$ \\
\hline 5. & Anto, SE & Main informant & Accounting Staff \\
\hline 6 & Dian Sjahrial. S.Kom & Main informant & $\begin{array}{l}\text { Subdivision of Program } \\
\text { Development and Budgeting } \\
\text { of Arifin Ahmad Hospital }\end{array}$ \\
\hline 7 & Devi Sandra, SP., MSI & $\begin{array}{l}\text { Supporting } \\
\text { informant }\end{array}$ & $\begin{array}{l}\text { Section Head of Jadirejo } \\
\text { Urban Village people's } \\
\text { welfare }\end{array}$ \\
\hline 8. & Dewi Handayani, SH., MH & Main Informant & $\begin{array}{l}\text { Head of the MSME } \\
\text { Empowerment Section }\end{array}$ \\
\hline
\end{tabular}

Source: BPKAD, 2020

To obtain information on the implementation of regional financial policies related to Covid-19. Direct observations are made at the Agency or office by seeing first hand how the process of implementing regional financial policies related to Covid-19 and the third is documentation. Documentation, namely by looking directly at budget documents, policy documents, and other related documents.

To test the validity of the data, the triangulation technique was used. Triangulation is a data collection technique by combining various data collection techniques and data sources (Sugiyono 2011; 330). Triangulation is done by triangulation of techniques and triangulation of sources. Technique triangulation was carried out using 3 data collection methods, namely in-depth interviews, observation, and documentation from the same data source. Meanwhile, source triangulation is done by conducting interviews from different sources.

For technical triangulation, for example, researchers conducted interviews and it was known that there was an allocation of expenditure that could be submitted by Regional Apparatus Organization (RAO). At that time the researcher made observations and documentation by checking related documents directly. For triangulation of sources, the researchers conducted interviews with various parties, for example from interviews with key informants it was known that there was a budget allocation that could be used by RAOs who needed Covid-19 snacks. conduct interviews with informants at the relevant RAOs.

Data analysis techniques are carried out directly when researching with the following procedures or stages: data collection stage, at this stage the researcher collects all field notes that have been made based on interviews and observations that have been made. The next stage is data reduction and categorization. At this stage, the process of simplifying and categorizing the data is carried out. Then displaying data, namely the process of displaying data from reduction and categorization in a matrix 
based on certain criteria. The conclusion is the drawing of conclusions, if the results of the data display show that the data obtained is sufficient and by the information required, then it begins to conclude using the theory and the results of the data in the field.

\section{Result and Discussion}

Changes or shifts in budgets can be made, one of which is during an emergency. The Covid-19 pandemic is an emergency disaster that has been regulated in the Presidential Decree Regarding the Designation of Non-Natural Disasters for the Spread of Corona Virus Disease 2019 (Covid-19) as a National Disaster. So that the government is required to make a budget shift accompanied by the issuance of Presidential Instruction Number 4 of 2020 concerning "refocusing activities, budget reallocation, and procurement of goods and services to accelerate the handling of the 2019 corona virus disease (Covid19)".

The Riau Provincial Government has made several budget shifts to comply with the provisions of Presidential Instruction Number 4 of 2020 concerning "refocusing activities, budget reallocation, and procurement of goods and services to accelerate the handling of the 2019 corona virus disease (Covid-19)." budget, researchers interviewed with the Head of the BPKAD Budget Division Ispan S. Syahputra as follows:

"For the first time, we will do the first move for Covid. The total budget is 74.9 billion in 4 RAOs with 5 activities of the health service, Arifin Ahmad Hospital, Petala Bumi Public Hospital, The handsome mental hospital is all indirect spending, so on the way, domestic instruction number 1 of 2020 was issued, the instructions were for the regions to allocate a budget for handling this Covid in unexpected expenditure items so that we allocate a budget of 377 billion in unexpected expenditure. At first 25 billion, well, we all posted it there, why did it go into unexpected shopping because this is an emergency, then the use of unexpected shopping can be done for direct use if there is an urgent emergency in the hope that handling Covid by using unexpected shopping can be more fast, like purchasing PPE using unexpected spending, then the Minister of Home Affairs Regulation No. 20 of 2020 follows, the content is almost the same as the Inmen No. 1 of 2020 Only moreThe focus is on the allocation of the shift, which is focused on handling 3 things, namely handling health, providing social safety nets, handling the economic impact, so we still use the BTT funds, then BPKAD makes another shift, namely reallocating the village financial aid budget which was originally 200 million per village. we reallocate 100 million per village "

The Riau Provincial Government immediately took steps to change the elaboration of the APBD by issuing a governor's decree regarding the establishment of an emergency alert status. At that time, the Governor of Riau had established a Riau Emergency Alert Regarding the spread of Covid-19, therefore it was permissible to make changes to the elaboration of the APBD, including budget expansion and budget regression.

It can be concluded that in facing the Covid-19 Pandemic, the Government has refocused the budget. Budget refocusing is concentrating or refocusing the budget on activities that were not previously budgeted through budget changes. Meanwhile, budget reallocation means budget reallocation. At this stage, it is clear that the Riau 
Provincial Government will also reallocate. This is indicated by making changes to the budget.

The Riau Provincial Government has refocused and reallocated the budget used for handling 3 things. First, handling health impacts, second handling social network security impacts, and third handling economic impacts. The government provides supporting facilities, handling infrastructure in the health sector. In dealing with the impact of social safety nets, the government provides social assistance and financial assistance. To deal with the economic impact, the government provides financial assistance to Micro, Small, and Medium Enterprises (MSMEs).

As in the interview above, in phase I the budget shift amounted to IDR 74,980,932,383, - conducted by 4 RAO for 5 activities (Health Department, Tampan Mental Hospital, Arifin Ahmad Regional General Hospital \& Petala Bumi Regional General Hospital). Phase II Budget Shift, In the process of compiling changes to the translation of this budget, Presidential Instruction No. 4 of 2020 was issued regarding the formation of a national Covid-19 Task Force and also the establishment of emergency alerts in Indonesia. On that basis, the government has shifted the budget from the regional incentive fund of 22 billion, all of which has been shifted to health care. The shift from Unexpected Expenditures of 377 billion was shifted to Financial Aid so that it could be channeled to Regencies and Cities. Phase IV budget shifts The Riau Provincial Government has reallocated and refocused by the Decree of the Governor of Riau Decree No. 28 years.

The administration is the administration for the recording of Covid-19 expenses. Administration includes the completeness of the documents used to record transactions, the person in charge, the duties and authorities of each party as well as the recording procedures. Therefore, the researcher interviewed the Head of Treasury of BPKAD Afdillah Arifin, SE., MM. Here are the results of the interview:

"... So this part of administration takes care of disbursement and distribution. The first use of the Covid budget was from the Social Assistance Shopping post to repatriate 10 students studying in Wuhan using BTT funds in the form of unplanned social assistance. This budget is the first budget used for handling Covid-19 before budget refocusing and reallocation occurs.

And then into the refocusing and budget reallocation period, during this period there were 4 shifts in the budget, the first shift was a shift in the forest and land fires budget, the second was a shift in the budget to direct spending, and then the third was from direct spending to BTT, and the last one from BTT to PMK

From this shift, there are 3 types of assistance, the first is urban village financial assistance of one hundred million rupiahs per village. Of the 12 districts and cities, which have distributed, namely Pekanbaru, Bengkalis, Meranti, Kampar. then subdistrict assistance of one hundred million and those that have distributed are Meranti, Bengkalis, Kampar. the third is special financial assistance for handling Covid-19, known as BLT from the provincial government. Of the 12 districts and cities, almost all have distributed it every 3 months, apart from the city of Pekanbaru which has only distributed for two months, Bengkalis has only distributed 1 month. Then the grant for Polda, budget for guarding border points, but for the Polda has not been distributed."

Disbursing funds for expected expenditures are used to facilitate budget disbursements for unexpected expenditures, such as budgets for civil service police 
units, regional police, transportation services. In addition, the disbursement of funds in the field of handling health impacts such as providing lodging for Covid-19 medical personnel, the Riau Province government also rented several hotels such as Arya Ambassador, Mona Hotel. Then for the general office, the task force is also budgeted for their operational costs such as their consumption. The budget for handling Covid-19 was also budgeted, including assistance from APH and APIP in the process of disbursing the BTT budget for handling Covid-19.

In the administration during the Covid-19 pandemic, no obstacles were found, this was strengthened by the results of interviews with the Head of Treasury BPKAD Afdillah Arifin, SE, MM who also stated as follows:

"... So far, no obstacles have been found in the disbursement process, because the Riau regional government policy has a mechanism that requires assistance from the inspectorate, the APIP district attorney, and also the Polda in reviewing every application for the use of the BTT budget, after being reviewed and accompanied by other supporting documents, then it can be realized. For the receipt of funding so far there have been no obstacles and is still quite under control, the difference is if there is a delay in transfer funds from the center, for now, the transfer funds for Quarter 1,2 and 3 have been received, while for Quarter 4 it will be received in next year."

The Riau Provincial Government budgeted a budget for handling the economic impact of around IDR 25.000 billion. For financial assistance to urban villages, the Government has channeled funds of IDR 100 million each. However, the distribution of handling the economic impact is rather difficult because we do not have an MoU with companies or businesses.

This was strengthened by in-depth interviews with the head of the BPKAD budget Ispan S. Syahputra HS, MM:

“...We also at BTT have also prepared, our estimates that are needed in handling the economic impact of around 25 billion are also constrained by yesterday's Sunday data, The governor has written to the Ministry of Home Affairs asking for certainty regarding the distribution mechanism whether it is possible again such as the pattern of direct cash assistance or what is appropriate because BPKAD is afraid that financial assistance is afraid that in the city districts it will be stuck or not distributed because the BPKAD has distributed all the assistance to the city regencies If the obstacles we get in the city district are because they don't have an MoU with a third party to distribute or their data needs to be re-verified so to deal with the economic impact on unexpected spending we have also prepared, we have calculated the estimate of around 25 billion but it has not been implemented to more details can be asked at the industry agency. "

To follow up on the results of the interview with the Head of BPKAD budgeting, the researcher conducted an in-depth interview with the industry agency, namely by Head of the MSME Empowerment Section Dewi Handayani, SH., MH who stated:

"... Until now we have not distributed Covid to MSMEs, this is because the available data is invalid, so we are updating the data again"

So for now there are still obstacles in the MoU and still need to update the data again for budget distribution in handling economic impacts.

Financial accountability is administrative evidence for activities that have been carried out or that have been budgeted for and basically for accounting and reporting there are 
no significant problems because a recording is based on transaction evidence. But accountability is different during the Covid-19 pandemic because there is a shift in the handling budget. This is confirmed by the results of interviews with Head of Accounting and Reporting BPKAD Hartono, Ak., M.Si who stated:

"Covid-19 is an extraordinary event and of course in handling it must be extraordinary too, every expense must have a record of the budget used. In the budget, there are 2 types, namely, direct expenditure and indirect expenditure."

Unexpected expenditure whose central recognition is in head of local government financial management office (PPKD), not in RAO so that it becomes an account called unexpected spending. In the technical implementation, all activities are carried out by technical RAOs but for the budget remains from PPKD as the manager, for example, the procurement of medical devices, RAO submits to PPKD with existing mechanisms and is processed with the provisions set by the Regional Government and after it is approved by the inspectorate with the counterpart team, the PPKD will disburse the BTT budget that has been submitted. In accounting, when the recording will be recorded in its realization form, BTT does not have details of the use of the budget. Different from reports in the form of activities, there are details on the use of the budget itself, as well as the accountability report (SPJ) for clear accountability. "

In the governor's regulation, it has also been arranged, when the RAO submits the BTT budget proposal, it must explain the details of the BTT budget used for anything. Attach a note on the use of the budget along with a summary of the use of the budget when reporting the SPJ to PPKD, then PPKD must detail the use of the BTT budget for this activity even though the recording still uses the BTT Journal. Therefore, in the regulation, the responsibility lies with the respective RAO and the PPKD will make a note to the financial report.

This is confirmed by the results of interviews with the Head of Sub Division of Program and Budget for Regional Hospital Arifin Dian Sharijal, S. Kom as follows:

“... For BTT disbursement itself directly from BPKAD. Meanwhile, the accountability report follows the existing procedures with KPA directly from the President Director of Arifin Achmad Hospital. "

Based on the results of the above research, it can be concluded that several things are related to the practice of managing unexpected expenditures in the Riau provincial government.

In the implementation of financial administration and accountability, the regional government itself should make clear regulations. The existence of this regulation is a guide in the management of government finances. For local governments, this regulation must be complemented by a regional regulation that will be used as the basis for regional financial management for each SKPD (Nadirsyah, 2016). This was disclosed by the Head of Subdivision for Planning and Programs at the Health Office Achmad Jajuli, SKM, MKM:

“... In the ministerial regulation, it only relates that transfers from BPKAD as PPKD to RAO accounts but forms of accountability and so on are still gray and until now the provincial government has not issued technical guidelines related to governance in its RAO yesterday, I tried to discuss it at BPKAD until now there is no answer. and even in the inspectorate there is no answer yet,actually it is a dilemma because it is still unclear until now in the second period in the provincial government, the story of $\mathrm{BTT}$ is almost always never smooth during the haze emergency so that until now we 
only optimize the existing funds because BPKAD does not want to be responsible in accordance with the proportion because BPKAD only thinks the money is it is entered in the official account and the service is responsible, so it is not clear how the budget is used so that often the issue is that it can be resolved 1x 24 hours but the regulations do not cover it because they only rely on the Minister of Home Affairs even though the Permendagri only records transfers to accounts even though may not be recorded in official accounts, Not allowed in this RAO accounting record because he is only the PPK actor in their PPTK in them they don't want to eat it which is difficult So at the time of making the receipt who is responsible for the PPTK receipt, until there is no answer to the agency using BTT money who is that so there is confusion because there is no clarity in regulations "

Looking at the practice of managing expenditures, especially Unexpected Expenditures at the Riau Provincial Government in dealing with Covid-19, there is a problem, namely the lack of regulations regarding how to record Unexpected Expenditures. In practice, for some RAOs, PPKD only transferred BTT directly to RAO accounts. This raises confusion for RAOs on how to record and be accountable for the BTT expenditure.

According to (Republic of Indonesia Government, 2006) stated, unexpected expenditure is expenditure for activities that are unusual or not expected to repeat themselves, such as the response to natural disasters and social disasters that were not predicted, including the return of excess regional revenues from previous years that have been closed. On (Government of the Republic of Indonesia, No 12 of 2019) states "unexpected expenditures are budgetary expenditures on APBD expenses for emergency purposes including urgent needs that cannot be predicted in advance ".

However, the use of BTT for the release of goods and services still raises concerns for DPOs due to the lack of regulations. This causes there is concern that government officials will be caught in a legal case because of the activities of procuring goods and services. Following the statement (Tejomurti, 2017) whereas on the one hand budget managers are required to optimize budget absorption to succeed in programs and activities, but these government officials also experience a dilemma because of the "euphoria" of law enforcers in examining and concluding that a government official is involved in a criminal act of corruption that can harm state finances.

In the issuance of BTT for the procurement of goods and services, as stated in (Presidential Decree No. 16 of 2018) Article 47 regarding the procurement of government goods and services, the implementation of the procurement of goods and services is carried out by the PA / KPA signed by the Commitment Making Officer (PPK). The Commitment Making Officer (PPK) is an important figure in the procurement of goods and services because the PPK is the person responsible for the implementation of the procurement of goods/services. (Presidential Decree 54 of 2010 Article 1, paragraph 7). So that PPK is responsible administratively, technically, and financially for the procurement of goods and services. As disclosed by the informant, PPK is under BPKAD, so it is difficult to implement expenses for Unexpected Expenditures according to regulations if budget Users do not appoint PPK.

Bangjana (2020) states that the solution to these problems can be done in a way local governments must make policies on Unexpected Spending Use Patterns (BTT). According to Porigin 162 (Permendagri No 21 of 2011), Article 69 PP 12 the Year 2019, and Article 4 Permendagri 20 the Year 2020 the BTT loading pattern itself is first: PDirect 
charges on Unexpected Expenditures Expenditures are borne directly on the BTT budget that is in the PPKD. Budget users remain in PPKD. How to Use Expenditures is charged directly to the BTT budget in PPKD. Budget users remain in PPKD. This pattern is carried out in conditions of emergency response to disasters, social conflicts, and/or extraordinary events. In the use of BTT Covid-19 using a direct charging pattern, SKPD BTT managers cannot be positioned as an accounting entity. But only as of the executor of the existing budget in PPKD. Because the budget does not change, the function of accounting records is in PPKD.

The problem that was found next was the need to determine the limits on spending usage. How to define expenditure that includes emergency handling will cause problems if there is no regulation from the Regional Government. This is supported by the results of an interview with the Head of Programming at the Health Office Achmad Jajuli, SKM, MKM:

"... Then the basic concept of BTT is the type of emergency shopping, what kind of shopping is meant in emergency shopping, and it is not clear, such as laptop shopping, whether it is included in emergency shopping or so on."

In determining the expenditures included in use in emergencies and urgency. There is confusion in the use of shopping because all conditions are emergency and urgent. Based on PP No.12 of 2019 article 69Emergencies are grouped: The emergency as referred to in Article 68 paragraph (1) includes: natural disasters, non-natural disasters, social disasters, and/or extraordinary events; carrying out search and rescue operations; and/or damage to facilities/infrastructure that can interfere with public service activities.

The urgent needs as referred to in Article 68 paragraph (1) include: regional needs in the context of basic public services whose budget is not yet available in the current fiscal year; Regional expenditures that are binding and expenditures that are mandatory; Regional Expenditures that are beyond the control of the Regional Government and cannot be predicted, as well as the mandate of statutory regulations; and/or Other Regional Expenditures which if postponed will result in greater losses for the Regional Government and/or the community.

The criteria for emergencies and urgent needs as referred to in paragraph (1) and paragraph (2) are stipulated in the Perda on APBD for the current year. Expenditures to fund emergencies for which the budget is not yet available are formulated in advance in the Local government department budget and work plan, except for disaster emergency response needs, social conflicts, and/or extraordinary events. Expenditures for emergency response needs for disasters, social conflicts, and/or extraordinary events as referred to in paragraph (4) shall be used by the provisions of laws and regulations. Expenditures to finance urgent needs for which no budget is available and/or an insufficient budget is available, formulated in advance in the Local government department budget and work plan and/or Amendments to the Budget implementation document of local government departments.

Guided by the Government Regulation and Permendagri above, the Regional Government can make regional regulations regarding emergency and urgent conditions so that they can be used as guidelines in implementing Unexpected Expenditures.

In terms of assistance from third parties, the procedure must be supported by a Handover Report (BAST), but after conducting in-depth interviews with BPKAD 
accounting and reporting staff Anto, S.E., namely not finding all BAST documents reported to BPKAD, he also stated as follows:

" Whether incoming or outgoing grants received by the task force / submitted to a third party are properly recorded, meanwhile according to the provisions, they must be recorded in the financial statements as grant expenses/income. Regarding the issuance of Permendagri 39, there are a number of issues that I have found to be problematic, related to the accountability of Covid funds which are recorded on regional apparatus. "

In connection with the accountability for contributions from third parties has been regulated in Permendagri No. 39 Procedures for implementation and administration as well as reporting and accountability for contributions from the public or third parties. (According to PP No.39 of 2020), receipt of grants from third parties in the form of fixed assets or goods. Head of RAO financial management office records donations in the form of LO Income on the Operational Report and fixed assets on the balance sheet when the donation is received by RAO. For the receipt of Current Assets in the form of inventories, the goods manager records the receipt and release of goods and takes stock taking at the end of the period. Based on stock opname Head of RAO financial management office reports current assets in the form of consumable inventory on operational reports and balance sheets.

Based on the above government regulations, local governments can compile more detailed regulations and make technical guidelines on procedures for recording and reporting on expenditures used for handling Covid-19, especially unexpected expenditures, so that there is no confusion in the implementation of policies that have been issued by the central government.

In the process of direct cash transfers, there are still obstacles, namely the DTKS which has not been updated. This resulted in the wrong targeting of those who received direct cash assistance. Strengthened by the results of an interview with the secretary of the rejosari kelurahan Devi Sandra, SP., MSI which stated the following:

"... If BLT is a sub-district, it only distributes because the data taken is still using old data and in the field, we often find duplicate data because there is also a division in this rejosari sub-district where the expansion of yellow bamboo is one of the BLT problems."

The availability of valid data supports the distribution of aid to the community so that it is right on target. Therefore, the government needs to improve the information system so that the available data is always updated. According to Anwar (2004), effective data management is a characteristic that needs to be considered in information systems. Things that need to be observed include the time to update files, accuracy in data input, maintenance of the unity of data stored in the system, security requirements for data that have been used, and good data backup facilities.

The importance of information systems for the government is a necessity that cannot be avoided. Especially with the increasing number of residents who have to be served in a relatively fast time, with the Covid-19 situation that requires us to always avoid physical contact and always keep a distance, therefore it cannot be denied that an information system must exist and be continuously updated to make work easier and present more accurate data. . In the current information age, the public also demands transparency on the procedures carried out by government officials. This aspect of transparency is also very easily fulfilled by the existence of an information system. 


\section{Conclusion}

The entry of the Covid-19 pandemic has an impact on various sectors. One sector that has an impact is the government sector. The government, which is an institution that must provide services to the community, is demanded to be able to provide its role in serving the community. Therefore, the government's policy that first issued Perpu No.1 of 2020, caused local governments to make changes to the budget by refocusing and reallocating the budget for use in the response to the Covid-19 pandemic outbreak. The results of refocusing and budget reallocation are used to address health impacts, social net safety impacts (JPS), and economic impacts. Spending for handling the impact of Covid-19 has had an impact on the management of government finances. This has an impact on budgeting. Based on the results of the research and analysis that has been described, it can be concluded that first, the Riau Provincial Government has carried out 4 times the shift in the budget used for handling Covid-19. Second, the regulations that have been issued by the government in recording unexpected expenditures are still insufficient or unclear, resulting in unclear authority between RAO and SKPD in the use of BTT. Therefore, it raises anxiety and fear in using BTT plus the euphoria of the law so that they are afraid of being caught in a legal case. Third, it is necessary to determine limits on the use of existing spending so that it is clear whether an expenditure is said to be an expense for unexpected expenditure. Fourth, details of the use of BTT are required. Unexpected Shopping is a single account so that the details of the shopping cannot be known. Therefore, additional notes are required which must be explained. Notes to Financial Statements. Fifth, This research has contributed to the Riau provincial government in terms of formulating policies in the management of government finances related to the Covid-19 disaster and other policies on the use of unexpected spending. This research can also be literature on public sector accounting, especially government accounting.

The author realizes that there are still various limitations in this study, for example, the writer cannot carry out the Focus Group Discussion technique, so that further research can conduct FGDs to analytical techniques using NVivo is useful for assisting qualitative research efficiently, helping consumption logic and research design, and providing facilities for content analysis.

\section{References}

Anwar. A. A. (2004). Human resource management of the first printing company. Bandung: PT. Rsodakarya.

Arifiyanto, D. F., \& Kurrohman, T. (2014). Accountability for managing village fund allocations in Jember Regency. Journal of Accounting and Financial Research, 2(3), 473-485. https://doi.org/10.17509/jrak.v2i3.6598

Asshidiqie, A. (2006). Introduction to Constitutional Law Volume II, Constitutional Court of the Republic of Indonesia

Budiarso, N., Tinangon, J., \& Rondonuwu, R. (2015). Analisis Efisiensi dan Efektivitas Pengelolaan Keuangan Daerah pada Dinas Pendapatan Daerah Kabupaten Minahasa. Jurnal Riset Ekonomi, Manajemen, Bisnis Dan Akuntansi, 3(4), 23-32.

Creswell.J.W. (2015). Qualitative Inquiry and Research Design: Choosing Among Five Approaches. SAGE Publication. 
Hasanah, U. (2019). Disaster Management Financial Accountability (Study at the Regional Disaster Management Agency of West Java Province). XXI, 34-39.

Kepres No 12. (2020). Regarding the Determination of Non-Natural Disaster for Corona Virus Disease 2019 as a National Disaster.

Meutia, I., \& Liliana. (2017). Pengelolaan Keuangan Dana Desa. Jurnal Akuntansi Multiparadigma, 8(2), 336-352. https://doi.org/10.18202/jamal.2017.08.7058

Nadirsyah, S. A. (2016). Regional Financial Supervision Of Report Quality principles of Government Accounting Standards. Journal of Master of Accounting.

Nafidah, L. N., \& Anisa, N. (2017). Akuntabilitas Pengelolaan Keuangan Desa di Kabupaten Jombang. Akuntabilitas, 10(2), 273-288. https://doi.org/10.15408/akt.v10i2.5936

Republic of Indonesia Government. (2020). Government Regulation of The Republic of Indonesia Number 39 of 2020 About Appropriate Accommodation For Persons With Disabilities In Jurisdiction Processes.

Republic of Indonesia Government. (2006). Minister Of Home Affairs Regulation Number 13 Of 2006 About Blood Finances Management Guidelines.

Republic of Indonesia Government. (2010). Regulation Of The President Of The Republic Of Indonesia Number 54 Of 2010 Concerning Procurement Of Government Goods / Services With Procurement Of Goods And Services.

Republic of Indonesia Government. (2011). Minister Of Home Affairs Regulation Number 21 Of 2011.About Second Amendment To Regulation Of The Minister Of Home Affairs Number 13 Of 2006 Concerning Regional Financial Management Guidelines.

Republic of Indonesia Government. (2018). Presidential Regulation No. 16 of 2018 about PRprocurement of government goods / services.

Republic of Indonesia Government. (2020). Government Regulations in Law of The Republic of Indonesia Number 1 Year 2020 Concerning Government Regulation in Lieu of Law (Perpu) concerning State Financial Policy and Financial System Stability for Handling the Corona Virus Disease 2019 (COVID-19) Pandemic and/or in Facing Threats That Endanger the National Economy and/or Financial System Stability.

Republic of Indonesia Government. (2020). Minister Of Home Affairs Regulation No. 20 Of 2020 About Accelerated Handling Of Covid 19 Within The Local Government.

Republic of Indonesia Government. (2020). Presidential Instruction of the Republic of Indonesia number 4 of 2020 concerning Refocussing Of Activities, Budget Realocation, And Procurement Of Goods And Services In Accelerating Handling Of Corona Virus Disease 2019 (Covid-19).

Rivani, E. (2019). Mekanisme, Jenis Pendanaan Dan Pertanggungjawaban Dana Penanggulangan Bencana Di Daerah (Mechanism, Type Of Funding, And Accountability Of Disaster Management Funds In Region). Kajian, 22(1), 59-70.

Satriajaya, J., Handajani, L., \& Putra, I. N. N. A. (2018). Pengelolaan Bantuan Keuangan Bersifat Khusus dari Pemerintah Kabupaten dalam Anggaran Pendapatan Dan Belanja Desa. Jurnal Akuntansi Aktual, 5(1), 1-14.

Sugiyono (2009). Qualitative Quantitative Research Methods And R\&D. Bandung: Alfabeta. 


\section{Basri, Hariadi \& Asra}

Management of Unexpected Expenditures for Covid-19 in Local Government

Tejomurti, K. (2017). Pertanggungjawaban Hukum yang Berkeadilan terhadap Aparatur Pemerintah pada Kasus Pengadaang Barang dan Jasa. Dialogia luridica: Jurnal Hukum Bisnis dan Investasi, 8(2), 42-52. https://doi.org/10.28932/di.v8i2.722.

Triani, N. N. A., \& Handayani, S. (2018). Praktik Pengelolaan Keuangan Dana Desa. Jurnal Akuntansi Multiparadigma, 9(1), 136-155.

https://doi.org/10.18202/jamal.2018.04.9009 